\title{
A geochemical approach to the restoration plans for the Odiel River basin (SW Spain), a watershed deeply polluted by acid mine drainage
}

\author{
Francisco Macías $^{1}$ - Rafael Pérez-López ${ }^{1}$ - Manuel A. Caraballo ${ }^{2,3}$. \\ Aguasanta M. Sarmiento ${ }^{1}$ - Carlos R. Cánovas ${ }^{1} \cdot$ Jose M. Nieto $^{1} \cdot$ Manuel Olías $^{1}$ • \\ Carlos Ayora ${ }^{4}$
}

Received: 22 June 2016 / Accepted: 28 November 2016/Published online: 10 December 2016

(C) Springer-Verlag Berlin Heidelberg 2016

\begin{abstract}
The Odiel River Basin (SW Spain) drains the central part of the Iberian Pyrite Belt (IPB), a world-class example of sulfide mining district and concomitantly of acid mine drainage (AMD) pollution. The severe AMD pollution and the incipient state of remediation strategies implemented in this region, coupled with the proximity of the deadline for compliance with the European Water Framework Directive (WFD), urge to develop a restoration and water resources management strategy. Furthermore, despite the presence of some reservoirs with acid waters in the Odiel basin, the construction of the Alcolea water reservoir has already started. On the basis of the positive results obtained after more than 10 years of developing a specific passive remediation technology (dispersed alkaline substrate (DAS)) for the highly polluted AMD of this region, a restoration strategy is proposed. The implementation of 13 DAS treatment plants in selected acid discharges along the Odiel and Oraque sub-basins and other restoration measurements of two acidic creeks is proposed as essential to obtain a good water quality in the future Alcolea reservoir. This restoration strategy is also suggested as an
\end{abstract}

Responsible editor: Philippe Garrigues

Francisco Macías

francisco.macias@dgeo.uhu.es

1 Earth Science Department, University of Huelva, Campus "El Carmen," Av. 3 de Marzo s/n, 21071 Huelva, Spain

2 Mining Engineering Department, University of Chile, Avda. Tupper 2069, 8370451 Santiago, Chile

3 Advanced Mining Technology Center, University of Chile, Avda. Tupper 2007, 8370451 Santiago, Chile

4 Institute of Environmental Assessment and Water Research, IDÆA-CSIC, Jordi Girona 18, 08034 Barcelona, Spain economically and environmentally sustainable approach to the extreme metal pollution affecting the waters of the region and could be considered the starting point for the future compliance with the WFD in the Odiel River Basin.

Keywords Odiel River Basin · Alcolea reservoir · European Water Framework Directive · Acid mine drainage $\cdot$ Dispersed alkaline substrate

\section{Introduction}

\section{Odiel River basin}

The Odiel River has the largest drainage basin in the Huelva province (SW Spain), with an area of $2330 \mathrm{~km}^{2}$ and a fluvial network of $1149 \mathrm{~km}$ of streams (Sarmiento et al. 2009a). The Odiel basin can be divided into three main sub-basins: Odiel, Oraque, and Meca (Fig. 1), with areas of 1401, 612, and $317 \mathrm{~km}^{2}$, respectively.

The Odiel basin is mainly underlain by materials from the Iberian Pyrite Belt (IPB), one of the largest sulfide provinces in the world (Sáez et al. 1999) that has been mined since the third millennium BC (Nocete et al. 2005) until the present days. This ancient mining has created a huge number of abandoned mine sites that generate a severe metallic pollution by acid mine drainage (AMD) in the Odiel River, causing a poor ecological and chemical quality of its waters (Sarmiento et al. 2009a).

Owing to the severe pollution of the Odiel River, it shows a low regulation and the largest reservoirs in the basin are Olivargas $\left(29 \mathrm{hm}^{3}\right)$ and Sancho $\left(58 \mathrm{hm}^{3}\right)$, which regulate the Olivargas and Meca rivers, respectively (Fig. 1), and both are affected by AMD (Sarmiento et al. 2009b). While the former 
Fig. 1 Odiel River basin, with its three sub-basins, the main mining districts, and the location of the future Alcolea reservoir

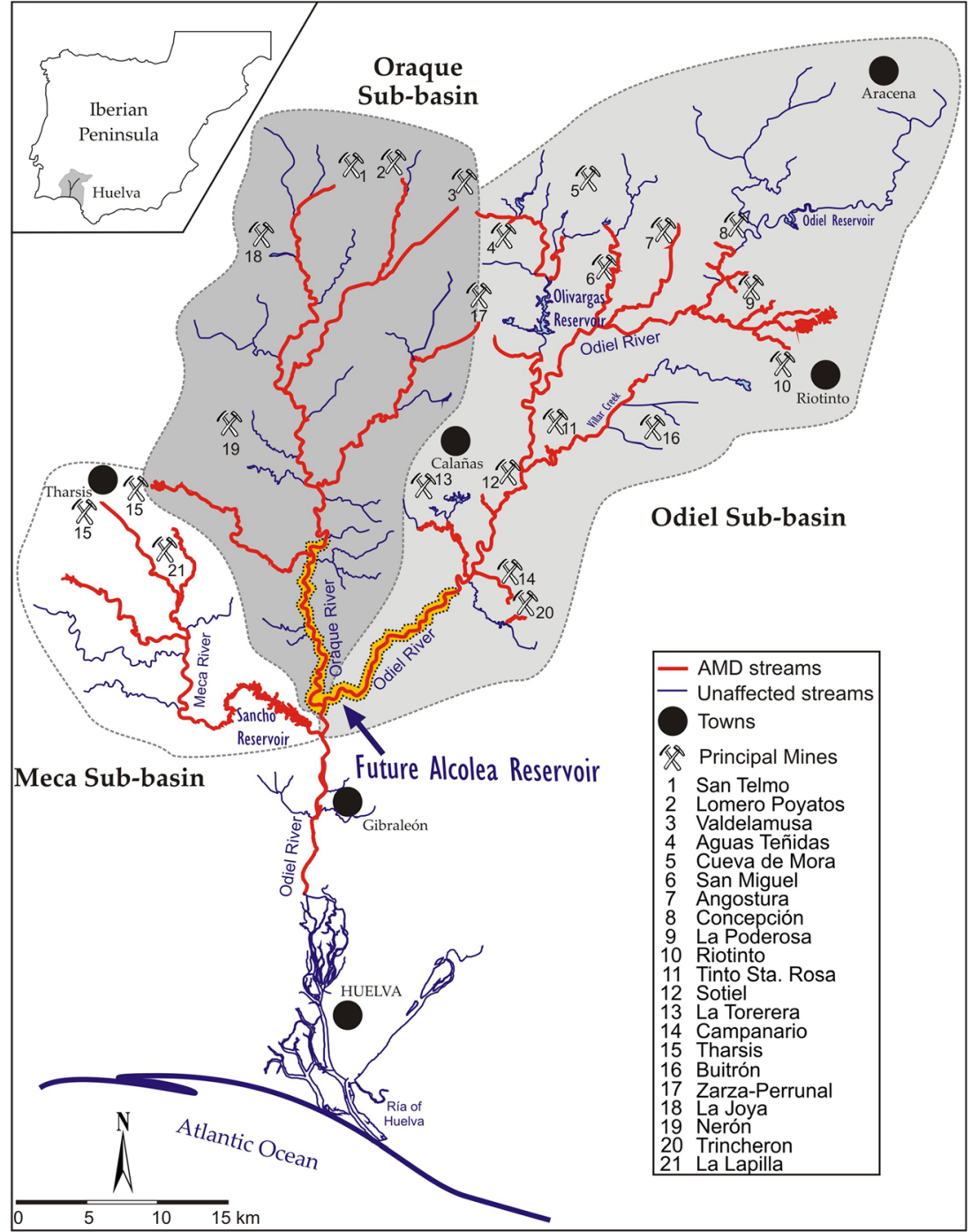

presents circum-neutral $\mathrm{pH}$ values and low metal concentrations, being used for drinking water supply after treatment, the latter shows a $\mathrm{pH}$ between 3 and 4 and high concentration of toxic elements (Sarmiento et al. 2009b) and has been classified as an extreme case of surface water pollution worldwide (Cánovas et al. 2016). Despite this fact, the construction of two reservoirs is planned in areas with a higher degree of mining pollution. The Alcolea reservoir $\left(247 \mathrm{hm}^{3}\right)$, with a final budget of almost $€ 164$ million, is the most advanced project, and its construction has already begun. Nevertheless, the water of the reservoir will be acidic if remediation measures are not put into practice (Olias et al. 2011).

On the other hand, the Odiel River merges with the Tinto River in a common estuary called Ría of Huelva (Fig. 1). The great ecological and social importance of this estuary is reflected in the protection legal figure of "biosphere reserve" given to the lower section of the Odiel estuary from UNESCO in 1983. However, the upper section of the estuary has $\mathrm{pH}$ values close to 3.6 and high concentration of dissolved metals, which inflict a high environmental impact in the estuarine system (Cánovas et al. 2007; Nieto et al. 2007).

\section{European Water Framework Directive}

The Directive 2000/60/EC of the European Parliament, so-called Water Framework Directive (WFD) (EU Commission 2000), established a communitarian frame of action in the scope of water policy. It was approved with the aim of merging in a unique legal text the regulations established in multiple norms regarding the aquatic environment and the control and prevention of pollution. Its main objective is to achieve a good ecological and chemical quality of all European waters by 2015 .

Nevertheless, the WFD allows the deadline prolongation in cases of technical feasibility, when improvements within the timescale would be economically unsustainable and if natural conditions do not foster the timely improvement. These conditions are met in the Odiel River basin due to the severe and widespread metal pollution. For these reasons, the regional 


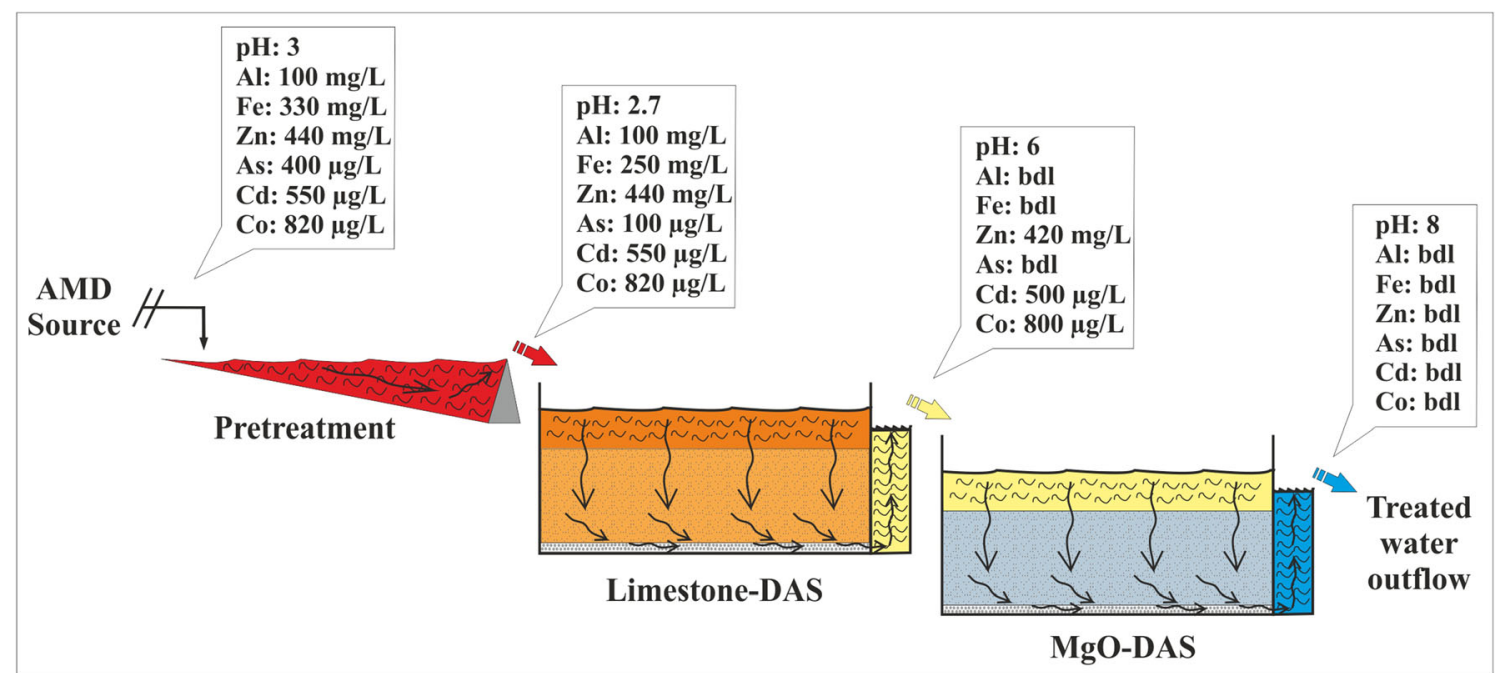

Fig. 2 Sketch of a basic DAS treatment plant illustrating its performance. Major chemical composition and pH values in the output of the different steps from the pilot-scale passive treatment system implemented in Monte Romero abandoned mine (Macías et al. 2012a, b)

authorities published the "Water Resources Management Plan", proposing to extend the deadline for 2021 and 2027 to perform remediation measures and to be in compliance with the WFD. According to economical and environmental criteria this document proposes the use of passive treatment systems as the most feasible and sustainable option to be implemented in these restoration strategies.

\section{Remediation strategies}

AMD pollution can be treated by active or passive technologies (Johnson and Hallberg 2005). An active treatment implies the use of energy and continuous addition of chemicals, whereas passive treatments rely on gravity forced water flow and biogeochemical reactions. AMD at abandoned mine sites is generally treated by the use of passive technologies (Younger et al. 2002). Conventional passive treatments (e.g., anoxic limestone drains, vertical flow wetlands, aerobic wetlands) have been successfully employed in coal mine districts affected by AMD (Younger et al. 2002). However, its use in the AMDs at the IPB or similar sites around the world is highly discouraged because the high acidity and metal content of these waters quickly promote clogging, thus losing the reactivity of the alkalinity-generating material employed (Ayora et al. 2013).

After more than 10 years of research and development of conventional passive treatment technologies in the acidic and metal-rich AMD from the IPB, a new design of alkaline passive treatment has been optimized for this type of waters. This novel treatment, known as dispersed alkaline substrate (DAS), comprises an inert wood shaving matrix, to supply high porosity and reduce the clogging problems, mixed with a fine-grained alkaline reagent to increase the substrate reactivity, which induces an increase of water $\mathrm{pH}$ after dissolution. A detailed explanation of the different laboratory and field experiments based on DAS passive treatment system can be looked up in Caraballo et al. (2009, 2011a), Macías et al. (2012a, b), and Ayora et al. (2013).

The good hydraulic performance of the DAS reactive substrate has been widely verified by mineralogical and geochemical approaches (Caraballo et al. 2011b), and a new potential economic source of metals by the exploitation of the DAS solid waste has been suggested (Pérez-López et al. 2011; Macías et al. 2012c). All these studies have demonstrated that the DAS system successfully treats metal-rich AMD from the IPB. Figure 2 shows the general performance of the DAS system as well as the chemical composition of waters and the removal efficiency obtained in each treatment step.

\section{Objectives}

The challenge of implementing the WFD fosters the development of new water treatment approaches. The directive encourages the use of modeling methods to optimize all stages of the treatment process, from characterization of background values and assessment of impacts to identification of the main restoration tasks for the improvement of water quality. The current study is based on the previous principles. The main aim of this work is to provide the basis for a future restoration planning in the Odiel basin.

\section{Methodology}

\section{Data collection and treatment}

A critical bibliographic review of the hydrochemistry of the main water courses comprising the Odiel and Oraque subbasins was performed (Asta et al. 2010; Cánovas et al. 2007; Galván et al. 2009; Grande et al. 2010; Sanchez-España et al. 
Table 1 Real values before and after acid inputs and modeling values without DAS treatment in the end of each polluted sector of the Odiel and Oraque sub-basins

\begin{tabular}{|c|c|c|c|c|c|c|c|c|}
\hline & Flow rate $(\mathrm{L} / \mathrm{s})$ & $\mathrm{pH}$ & $\mathrm{Al}(\mathrm{mg} / \mathrm{L})$ & $\mathrm{Ca}(\mathrm{mg} / \mathrm{L})$ & $\mathrm{Cu}(\mathrm{mg} / \mathrm{L})$ & $\mathrm{Fe}(\mathrm{mg} / \mathrm{L})$ & $\mathrm{SO}_{4}(\mathrm{mg} / \mathrm{L})$ & $\mathrm{Zn}(\mathrm{mg} / \mathrm{L})$ \\
\hline \multicolumn{9}{|l|}{ Odiel sub-basin } \\
\hline Odiel pre-AMDs real ${ }^{\mathrm{a}}$ & 110 & 8.7 & 0 & 30 & 0 & 0 & 10 & 0 \\
\hline Odiel final sector real ${ }^{\mathrm{a}}$ & n.a. & 3 & 13 & 51 & 5 & 18 & 512 & 9 \\
\hline Odiel final sector modeled & 124 & 3 & 21 & 36 & 7 & 60 & 558 & 10 \\
\hline Seca pre-AMD real ${ }^{\mathrm{b}}$ & n.a & 7.2 & 0 & 17 & 0 & 0 & 30 & 0 \\
\hline Seca post-AMD real ${ }^{\mathrm{a}}$ & n.a. & 5.6 & 3 & 5 & 3 & 1 & 69 & 0 \\
\hline Seca final sector modeled & 10.4 & 6.3 & 2 & 17 & 1 & 0 & 79 & 0 \\
\hline Escalada pre-AMD real ${ }^{\mathrm{a}}$ & 22.6 & 8.2 & 0 & 28 & 0 & 0 & 10 & 0 \\
\hline Escalada post-AMD real ${ }^{\mathrm{a}}$ & 18 & 3.7 & 5 & 36 & 1 & 11 & 282 & 1 \\
\hline Escalada final sector modeled & 24.1 & 4.7 & 1 & 33 & 2 & 90 & 380 & 1 \\
\hline Olivargas pre-AMD real $^{\mathrm{a}}$ & n.a. & 7 & 0 & 8 & 0 & 0 & 35 & 0 \\
\hline Olivargas post-AMD real ${ }^{\mathrm{a}}$ & n.a. & 4.9 & 1 & 8 & 0 & 2 & 32 & 0 \\
\hline Olivargas final sector modeled & 11 & 4.5 & 3 & 33 & 0 & 1 & 245 & 0 \\
\hline Villar pre-AMD real ${ }^{\mathrm{a}}$ & n.a. & 6.5 & 0 & 25 & 0 & 0 & 109 & 0 \\
\hline Villar post-AMD real ${ }^{\mathrm{a}}$ & n.a. & 2.8 & 32 & 122 & 4 & 15 & 1024 & 26 \\
\hline Villar final sector modeled & 11.4 & 4.4 & 6 & 45 & 3 & 107 & 503 & 9 \\
\hline Aguas Frias pre-AMD real ${ }^{\mathrm{b}}$ & n.a. & 7.2 & 0 & 17 & 0 & 0 & 30 & 0 \\
\hline Aguas Frias post-AMD real ${ }^{\mathrm{a}}$ & 30 & 3.2 & 9 & 45 & 1 & 39 & 483 & 9 \\
\hline Aguas Frias final sector modeled & 11.3 & 3.3 & 5 & 33 & 1 & 38 & 345 & 6 \\
\hline Galaparosa pre-AMD real ${ }^{\mathrm{a}}$ & n.a. & 7.4 & 0 & 15 & 0 & 0 & 63 & 0 \\
\hline Galaparosa post-AMD real ${ }^{\mathrm{a}}$ & 16 & 5.2 & 4 & 34 & 1 & 6 & 252 & 5 \\
\hline Galaparosa final sector modeled & 11 & 4.5 & 4 & 40 & 2 & 6 & 314 & 4 \\
\hline \multicolumn{9}{|l|}{ Oraque sub-basin } \\
\hline Gonzalo pre-AMD real ${ }^{\mathrm{b}}$ & n.a. & 7.2 & 0 & 17 & 0 & 0 & 30 & 0 \\
\hline Gonzalo post-AMD real ${ }^{\mathrm{a}}$ & 2 & 2.6 & 756 & 110 & 4 & 3951 & 13,783 & 4 \\
\hline Gonzalo final sector modeled & 12 & 2.6 & 55 & 16 & 0 & 218 & 1069 & 0 \\
\hline Pelada pre-AMD real $^{\mathrm{a}}$ & n.a. & 6.4 & 0 & 5 & 0 & 0 & 38 & 0 \\
\hline Pelada post-AMD real ${ }^{\mathrm{a}}$ & 18 & 3.3 & 11 & 51 & 1 & 4 & 440 & 3 \\
\hline Pelada final sector modeled & 15 & 3.2 & 17 & 163 & 0 & 116 & 1303 & 5 \\
\hline Tamujoso pre-AMD real ${ }^{\mathrm{b}}$ & n.a. & 7.2 & 0 & 17 & 0 & 0 & 30 & 0 \\
\hline Tamujoso post-AMD real ${ }^{\mathrm{a}}$ & 5 & 2.5 & 39 & 39 & 7 & 213 & 1336 & 7 \\
\hline Tamujoso final sector modeled & 12 & 4.2 & 45 & 43 & 4 & 383 & 1498 & 8 \\
\hline Panera pre-AMD real ${ }^{\mathrm{b}}$ & n.a. & 7.2 & 0 & 17 & 0 & 0 & 30 & 0 \\
\hline Panera post-AMD real & n.a. & n.a. & n.a. & n.a. & n.a. & n.a. & n.a. & n.a. \\
\hline Panera final sector modeled & 13.6 & 2.7 & 200 & 56 & 22 & 314 & 3729 & 58 \\
\hline
\end{tabular}

n.a. not analyzed

${ }^{\text {a }}$ Sarmiento (2007)

${ }^{\mathrm{b}}$ Sarmiento et al. (2009a)

2005a, b; Sarmiento 2007). The dataset employed in this study can be consulted in Appendix Table 3. The chemical composition of the most relevant AMD discharges (mine adits and shafts, pit lakes and acid reservoirs outputs, and spoil heap leachates) was obtained from Sanchez-España et al. (2005a, b), Sarmiento (2007), and Asta et al. (2010). Hydrochemical data of the main creeks and rivers suffering from low level of pollution (or none) by AMD were obtained from Sarmiento (2007). When hydrochemical data of non-affected streams were not available, background values for these area provided by Sarmiento et al. (2009a) were used. This dataset was geochemically modeled by the code PHREEQC Interactive 2.15.0 (Parkhurst and Appelo 1999). The thermodynamic database WATEQ4F (Ball and Nordstrom 1991) was enlarged with the solubility constants (Ks) for schwertmannite according to Bigham et al. (1996) and Yu et al. (1999).

\section{Conceptual design of the geochemical model}

A geochemical model is proposed to predict the water chemistry under two different scenarios: (1) baseline conditions and
(2) after passive treatment implementation. The geochemical modeling of baseline conditions is only performed for validation purposes by comparing modeled to measured values of different parameters (Table 1).

The geochemical model applied to the Odiel River consists in a mixing model using the "MIX" PHREEQC data block, which defines mixing fractions of aqueous solutions. Mixing fractions were obtained from data reported in literature. The model is subsequently improved by applying some geochemical constraints using the "EQUILIBRIUM PHASES" data block, which allows phase assemblages to react with an aqueous solution. These geochemical constraints are based on a previous analysis of the saturation state of main minerals commonly found in AMD environments relative to water samples. In this way, all mineral phases found oversaturated relative to water in each sample were forced to reach equilibrium, i.e., schwertmannite, jarosite, and ferrihydrite for Fe minerals; basaluminite, alunite, amorphous $\mathrm{Al}(\mathrm{OH})_{3}$, and gibbsite for $\mathrm{Al}$ minerals; and some soluble salts such as gypsum, melanterite, and copiapite.

Equilibrated waters are subsequently mixed with downstream discharge and so on. Modeled values are compared with those 


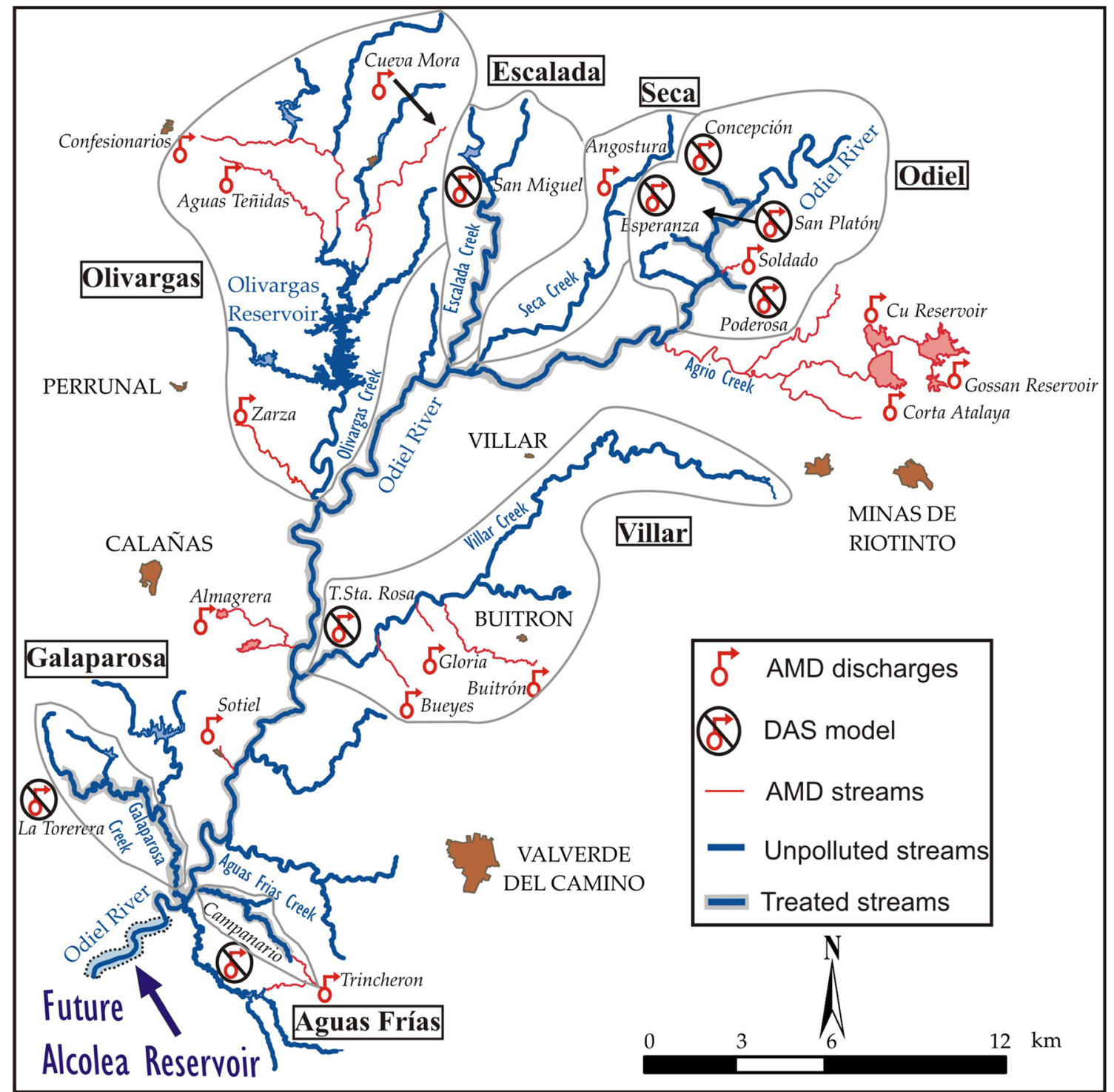

Fig. 3 Odiel sub-basin with the main AMD discharges. Some DAS treatment plants are strategically planned in this sub-basin (DAS model in the figure legend)

measured in real conditions in each sub-basin for validation purposes. Finally, the sample procedure is followed to perform a mixing model including the operation of different DAS plants located at strategic points in each sub-basin. The model was performed during high and low flow rate scenarios, but for the sake of simplicity, only results obtained during the extremely pollutant scenario, when the lowest flows are recorded, are presented.

\section{Results and discussion}

\section{Validation of the model}

As can be seen in Table 1, the validation of the model evidences some differences between modeled and measured values in different points. For instance, modeled $\mathrm{Fe}$ values are commonly higher than those measured (e.g., Odiel River; Table 1). These differences can be mainly attributed to the limitation of the model to consider reactive transport processes along the channels. Dispersion, diffusion, and transient storage may play an important role in element transport in these watercourses, especially during low flow rate scenarios such as that modeled. The higher residence time of water could enhance intense $\mathrm{Fe}$ precipitation processes that are not considered by the model. Another weak point of the model could be the inability to reflect the $\mathrm{Fe}$ oxidation processes catalyzed by bacterial activity. While $\mathrm{Fe}(\mathrm{II})$ remains dissolved at $\mathrm{pH}$ values of Odiel waters, $\mathrm{Fe}(\mathrm{III})$ is prone to precipitate. The model also disregards evaporative processes that play a key role in temporal storage of acidity and metals in semiarid 
Table 2 Real values and model with DAS plants implemented values in the end of each polluted sector of the Odiel and Oraque sub-basins

\begin{tabular}{|c|c|c|c|c|c|c|c|c|}
\hline & Flow rate $(\mathrm{L} / \mathrm{s})$ & $\mathrm{pH}$ & $\mathrm{Al}(\mathrm{mg} / \mathrm{L})$ & $\mathrm{Ca}(\mathrm{mg} / \mathrm{L})$ & $\mathrm{Cu}(\mathrm{mg} / \mathrm{L})$ & $\mathrm{Fe}(\mathrm{mg} / \mathrm{L})$ & $\mathrm{SO}_{4}(\mathrm{mg} / \mathrm{L})$ & $\mathrm{Zn}(\mathrm{mg} / \mathrm{L})$ \\
\hline \multicolumn{9}{|l|}{ Odiel sub-basin } \\
\hline Odiel final sector real ${ }^{\mathrm{a}}$ & n.a. & 3 & 13 & 51 & 5 & 18 & 512 & 9 \\
\hline Odiel modeling with DAS & 124 & 8.1 & 0 & 50 & 0 & 0 & 305 & 0 \\
\hline Escalada post-AMD real $^{\mathrm{a}}$ & 18 & 3.7 & 5 & 36 & 1 & 11 & 282 & 1 \\
\hline Escalada modeling with DAS & 24.1 & 8.2 & 0 & 31 & 0 & 0 & 187 & 0 \\
\hline Villar post-AMD real $^{\mathrm{a}}$ & n.a. & 2.8 & 32 & 122 & 4 & 15 & 1024 & 26 \\
\hline Villar modeling with DAS & 11.4 & 6.3 & 0 & 147 & 0 & 0 & 445 & 0 \\
\hline Aguas Frias post-AMD real ${ }^{\mathrm{a}}$ & 30 & 3.2 & 9 & 45 & 1 & 39 & 483 & 9 \\
\hline Aguas Frias modeling with DAS & 11.3 & 6.5 & 0 & 121 & 0 & 0 & 350 & 0 \\
\hline Galaparosa post-AMD real $^{\mathrm{a}}$ & 16 & 5.2 & 4 & 34 & 1 & 6 & 252 & 5 \\
\hline Galaparosa modeling with DAS & 11 & 6.6 & 0 & 72 & 0 & 0 & 266 & 0 \\
\hline \multicolumn{9}{|l|}{ Oraque sub-basin } \\
\hline Gonzalo post-AMD real ${ }^{\mathrm{a}}$ & 2 & 2.6 & 756 & 110 & 4 & 3951 & 13,783 & 4 \\
\hline Gonzalo modeling with DAS & 12 & 8.4 & 0 & 315 & 0 & 0 & 929 & 0 \\
\hline Pelada post-AMD real ${ }^{\mathrm{a}}$ & 18 & 3.3 & 11 & 51 & 1 & 4 & 440 & 3 \\
\hline Pelada modeling with DAS & 15 & 6.3 & 0 & 82 & 0 & 0 & 351 & 0 \\
\hline Tamujoso post-AMD real ${ }^{\mathrm{a}}$ & 5 & 2.5 & 39 & 39 & 7 & 213 & 1336 & 7 \\
\hline Tamujoso modeling with DAS & 12 & 6.6 & 0 & 304 & 0 & 0 & 1074 & 0 \\
\hline Panera post-AMD real ${ }^{\mathrm{b}}$ & n.a. & n.a. & n.a. & n.a. & n.a. & n.a. & n.a. & n.a. \\
\hline Panera modeling with DAS & 13.6 & 8.3 & 0 & 386 & 0 & 0 & 1687 & 0 \\
\hline
\end{tabular}

n.a. not analyzed

${ }^{\text {a }}$ Sarmiento (2007)

${ }^{\mathrm{b}}$ Sarmiento et al. (2009a)

AMD-affected catchments (e.g., Cánovas et al. 2008). This could also cause differences between modeled and measured values of not only $\mathrm{Fe}$ but also $\mathrm{pH}, \mathrm{Al}$, sulfate, $\mathrm{Mg}$, and $\mathrm{Ca}$.

On the contrary, when real data show a lower degree of AMD pollution than the modeled ones (e.g., Galaparosa creek in Table 1), it could be due to diffuse sources of pristine waters that cause dilution process and are not being taken into account in the model. Despite the differences observed in the validation processes, the same procedure was applied including selected DAS treatment plants as a preliminary approach for the restoration of the catchment.

\section{Restoration strategy of the Odiel and Oraque sub-basin based on passive remediation systems}

On the basis of the results obtained after the successful implementation of the DAS remediation technology in a highly metal polluted AMD at the IPB (Fig. 2), the remediation effect of several DAS treatment plants strategically located in the Odiel and Oraque sub-basins was modeled. The model did not include the Meca sub-basin because the main contributors correspond to diffuse sources (i.e., spoil heaps, low-grade ore stockpiles, leaching heaps), and thus, the application of DAS technology would not be cost-effective. The main limiting factors for the real implementation of a DAS passive treatment in the field were the flow rate $(5 \mathrm{~L} / \mathrm{s}$ is the maximum flow rate that the treatment can economically treat) and the geographic situation of the discharge. Another key limiting factor to decide the suitability of implementing a DAS treatment at a specific site is the chemistry of the waters after the mixture. To this respect, the hydrochemical threshold was employed to consider that a water has good chemical quality if $\mathrm{pH}>6$ and toxic metals are absent.

\section{Odiel sub-basin}

This is the largest drainage network in the Odiel basin and the main contributor to the projected Alcolea reservoir (Fig. 1). Almost 20 abandoned mines are located in this sub-basin with around 23 point AMD discharges (Fig. 3). The modeled water quality for each sector after DAS plant implementation is shown in Table 2. The absence of DAS systems in some AMD sites is due to natural attenuation of pollution after mixing with unpolluted streams (e.g., Angostura AMD in Seca creek, Fig. 3) or DAS-treated effluents (e.g., Zarza discharge in Odiel 
Fig. 4 Oraque sub-basin with the main AMD discharges. Some DAS treatment plants are strategically planned in this sub-basin (DAS model in the figure legend)

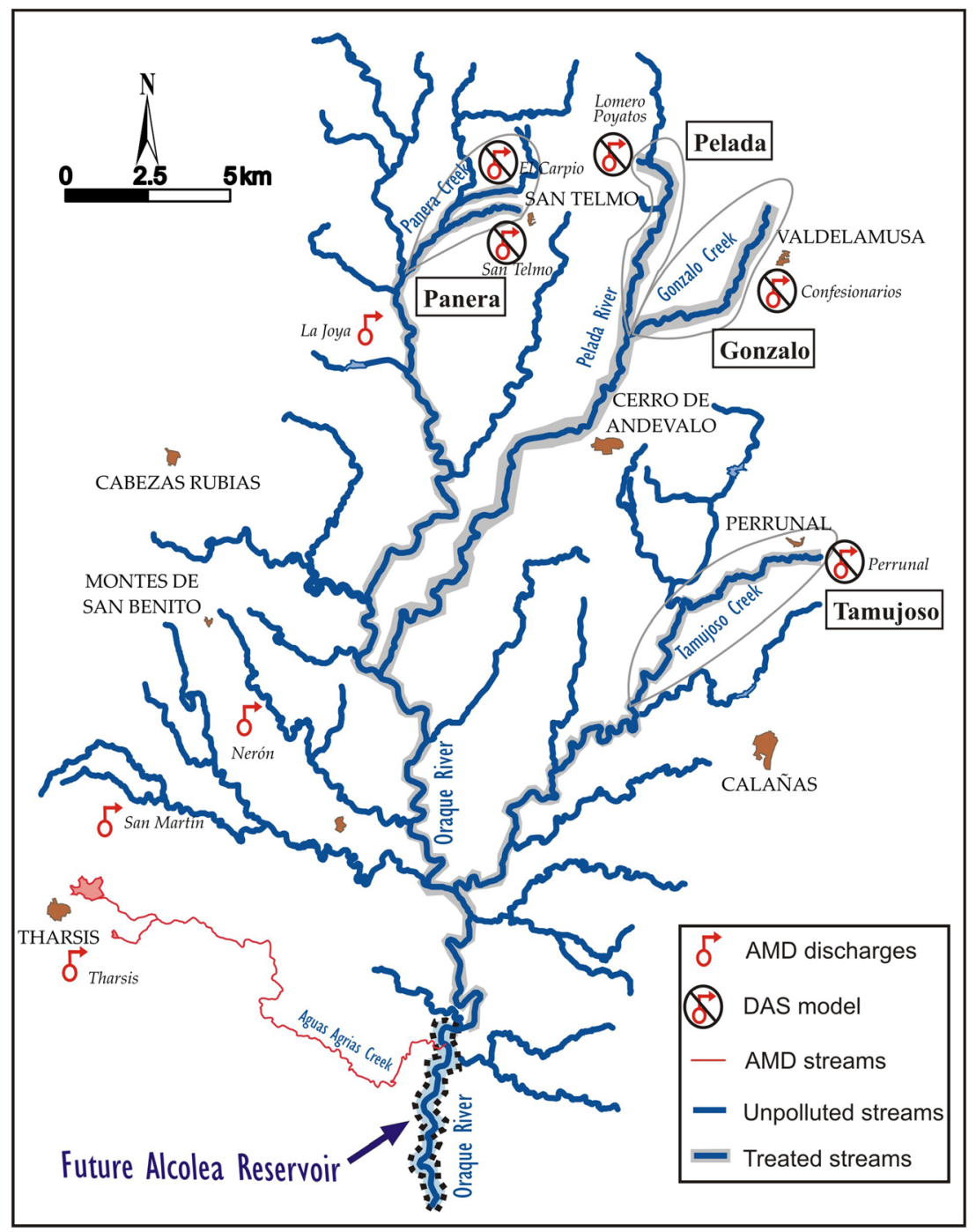

River, Fig. 3); therefore, the implementation of DAS systems in these points would be needless.

Taking into account these practical considerations, we considered the strategic implementation of eight DAS treatment plants in the Odiel sub-basin (Fig. 3). In this sense, two of these proposed plants (Concepción and Esperanza) are currently working financed by the EU LIFE+ program (LIFE-ETAD project, www.life-etad. com) and the national government, respectively. This must be considered a first step to improve the water quality in the river, because only 8 of the 23 acid discharges are treated. It is necessary to remind that despite these remediation efforts, several acidic streams would not be still in compliance with the WFD regulations.

Notwithstanding, this restoration strategy for the Odiel subbasin would not have the proposed beneficial effect in the main course of the Odiel River after the confluence with the Agrio creek (Fig. 3). This acid creek presents an average $\mathrm{pH}$ of
2.8 (minimum of 2.58 and maximum of 3.18 ), mean concentrations of $429 \mathrm{mg} / \mathrm{L}$ for $\mathrm{Al}$ (minimum of $133 \mathrm{mg} / \mathrm{L}$ and maximum of $1140 \mathrm{mg} / \mathrm{L}$ ), and $264 \mathrm{mg} / \mathrm{L}$ as average for Fe (minimum of $57 \mathrm{mg} / \mathrm{L}$ and maximum of $554 \mathrm{mg} / \mathrm{L}$ ). The mean flow rate is $873 \mathrm{~L} / \mathrm{s}$, with 20 and $5040 \mathrm{~L} / \mathrm{s}$ as minimum and maximum values, respectively; these data were obtained from 11 samplings in both dry and wet periods and just before its confluence with the Odiel River (Sarmiento 2007). The pollution sources that affect this creek come from the Ríotinto mining district. Some of these sources present very high flow rates (e.g., $90 \mathrm{~L} / \mathrm{s}$ from Corta Atalaya pit lake or $220 \mathrm{~L} / \mathrm{s}$ from $\mathrm{Cu}$ Reservoir tailing impoundment; Sanchez-España et al. 2005a). This flow rates preclude the use of a DAS treatment system or any other passive treatment systems. In this area, other measures must be taken. Nevertheless, at the present time, the Riotinto mine is working, and according to the environmental conditions imposed by the regional authorities, acidic discharges must be reduced by $20 \%$ before the third exploitation year, $50 \%$ before the sixth year, and totally before 
the tenth year. The mine company is currently facing this issue by active treatment technologies, while the decommissioning project considers the DAS passive technology to treat the acid waters.

\section{Oraque sub-basin}

The Oraque sub-basin is subjected to fewer acid inputs than the Odiel with only nine mines generating AMD in its drainage network (Fig. 4). Moreover, some of the polluting sources (La Joya, Nerón, and San Martín) do not cause any relevant depletion in the quality of the surrounding waters (Fig. 4). On the contrary, some other mines like San Telmo and Perrunal generate extreme metal-polluted AMDs (Appendix Table 3).

To improve significantly the water quality of the Oraque River network drainage, the installation of only five DAS treatment plants would be necessary (Fig. 4 and Table 2). This remediation strategy would also imply the remediation of almost all the acid discharges characterized in this region, implying the restoration of practically all the sub-basin. However, a similar situation than the one already explained for the Agrio creek in the Odiel sub-basin can be observed for the Aguas Agrias creek in the Oraque sub-basin (Fig. 4). This creek is affected by several acid discharges from the Tharsis mines, whose flow rates are too high for passive remediation. Sanchez-España et al. (2005a) identified a discharge from a waste rock pile leaching $15 \mathrm{~L} / \mathrm{s}$. The implementations of active treatments or other measures such as isolation with impervious covers to reduce the drainage generation are recommended as the most feasible measurements for this creek.

\section{Conclusions}

The main objective of the WFD is to achieve a good ecological and chemical quality for all European waters by 2015 . Compliance with these regulations in the Odiel River basin seems to be impossible. The Andalusia Regional Government has proposed 2021 and 2027 as new deadlines for the application of the WFD, but even with these new deadlines, the magnitude and ubiquity of the AMD pollution in this region make the WFD economically and socially unfeasible. We propose a rational use of the economic, energetic, and natural resources to improve considerably the water quality in the Odiel River basin, although the WFD regulations were not completely met.

Thirty-two AMD discharges from 30 different mines located in the Odiel and Oraque sub-basins were modeled. The validation of the model evidenced some limitations (i.e., inability to model reactive transport processes, biological oxidation of $\mathrm{Fe}$, and evaporative processes of waters) to accurately predict the chemical composition of water during mixing. According to our simulation, the existence of diffuse sources could also be inferred, so the performance of tracer injection tests together with synoptic samplings in these watercourses is highly encouraged.

The restoration strategy proposed in this work is based not only in the model calculated including the DAS treatment technology but also on a detail comprehension of the AMD problematic in the region and of the different passive and active treatment technologies available to date. The implementation of 13 DAS treatment plants to remediate some affordable acid discharges located along the two sub-basins would produce the recovery of $128 \mathrm{~km}$ of streams, and it would be a first step in the basin restoration. Also, a significant decrease in the acid inputs of the future Alcolea reservoir is expected. Nevertheless, the elimination of the acid inputs of the Agrio creek from the Río Tinto mines, which is currently conducted by active technologies by the mine company, is essential to obtain a good water quality in the future Alcolea reservoir. However, if these measures are not maintained along the time (e.g., due to the close of the mine), the costs of these technologies would be unaffordable by the regional authorities and other restoration measures may be conducted in the Agrio creek (i.e., waste dump isolation with impervious covers to mitigate the AMD generation and the deviation of the Agrio creek to the Tinto River basin). On the other hand, the reopening of mines due to the increase of the $\mathrm{Cu}$ price in the international markets can be other interesting opportunity to reduce the enormous contaminant load reaching the drainage network of the Odiel River due to the obligation of mining companies to face inherited environmental liabilities.

Acknowledgements This work was supported by the Spanish Ministry of Economic and Competitiveness through the projects EMPATIA (CGL2013-48460-C2-1-R) and SCYRE (CGL2016-78783-C2-1-R) and LIFE-ETAD project (LIFE12 ENV/ES/000250) and partially financed by Program U-INICIA VID 2014, grant 193, University of Chile, and by CONICYT, Program Fondecyt Iniciacion, Project No 111500002 . R. Pérez-López also thanks the Spanish Ministry of Science and Innovation and the "Ramón y Cajal Subprogramme" (MICINN-RYC 2011). M.A. Caraballo gratefully acknowledges the support from the Advanced Mining Technology Center of the University of Chile. C.R. Cánovas was funded by the European Union's Seventh Framework Program, Marie Skłodowska-Curie actions, and the Ministry of Economy, Innovation, Science and Employment of the Junta de Andalucía by the program Talent Hub (COFUND-Grant Agreement 291780). We would also like to thank Dr. Philippe Garrigues (editor in chief) and an anonymous reviewer for the support and comments that significantly improved the quality of the original manuscript. 


\section{Appendix}

Table 3 Database employed in this study after the bibliographic critical review

\begin{tabular}{|c|c|c|c|c|c|c|c|c|c|c|c|c|c|c|c|}
\hline Name & Type & $\begin{array}{l}\text { Flow rate } \\
(\mathrm{L} / \mathrm{s})\end{array}$ & $\mathrm{pH}$ & $\mathrm{Pe}$ & Alk & $\begin{array}{l}\mathrm{Al} \\
(\mathrm{mg} / \\
\mathrm{L})\end{array}$ & $\begin{array}{l}\mathrm{Ca} \\
(\mathrm{mg} / \mathrm{L})\end{array}$ & $\begin{array}{l}\mathrm{Cu} \\
(\mathrm{mg} / \mathrm{L})\end{array}$ & $\begin{array}{l}\mathrm{Fe} \\
(\mathrm{mg} / \\
\mathrm{L})\end{array}$ & $\begin{array}{l}\mathrm{K} \\
(\mathrm{mg} / \\
\mathrm{L})\end{array}$ & $\begin{array}{l}\mathrm{Mg} \\
(\mathrm{mg} / \mathrm{L})\end{array}$ & $\begin{array}{l}\mathrm{Mn} \\
(\mathrm{mg} / \mathrm{L})\end{array}$ & $\begin{array}{l}\mathrm{Na} \\
(\mathrm{mg} / \mathrm{L})\end{array}$ & $\begin{array}{l}\mathrm{SO}_{4} \\
(\mathrm{mg} / \mathrm{L})\end{array}$ & $\begin{array}{l}\mathrm{Zn} \\
(\mathrm{mg} / \mathrm{L})\end{array}$ \\
\hline Concepción $^{\mathrm{a}}$ & Pit lake & 2.8 & 3.1 & 12 & bdl & 157 & 78 & 13 & 1089 & 1 & 177 & 46 & 9 & 5117 & 111 \\
\hline San Platón ${ }^{\mathrm{b}}$ & Mine adit & 2 & 2.5 & 10 & bdl & 247 & 108 & 69 & 1780 & 3 & 85 & 5 & 25 & 5850 & 227 \\
\hline Esperanza $^{\mathrm{b}}$ & Mine adit & 2.2 & 2.7 & 10 & bdl & 152 & 103 & 39 & 965 & 4 & 100 & 3 & 25 & 3710 & 24 \\
\hline Soldado ${ }^{\mathrm{b}}$ & Mine adit & 2 & 2.5 & 11 & bdl & 33 & 31 & 5 & 147 & 2 & 30 & 1 & 19 & 800 & 8 \\
\hline Poderosa ${ }^{a}$ & Mine adit & 5 & 2.1 & 10 & bdl & 232 & 53 & 122 & 1330 & 2 & 46 & 6 & 13 & 5690 & 550 \\
\hline Odiel $^{\mathrm{a}}$ & $\begin{array}{c}\text { Polluted } \\
\text { river }\end{array}$ & n.a. & 2.9 & 13 & bdl & 13 & 51 & 5 & 18 & 2 & 41 & 3 & 23 & 512 & 9 \\
\hline Corta Atalaya ${ }^{\mathrm{b}}$ & Pit lake & 90 & 2.7 & 10 & bdl & 1810 & 325 & 183 & 1290 & bdl & 1800 & 251 & 11 & 23,300 & 463 \\
\hline $\mathrm{Cu}$ Reservoir $^{\mathrm{b}}$ & $\begin{array}{c}\text { Reservoir } \\
\text { output }\end{array}$ & 220 & 4.6 & 8.1 & bdl & 30 & 382 & 18 & 4 & 10 & 87 & 7 & 94 & 1670 & 12 \\
\hline Agrio $^{a}$ & $\begin{array}{c}\text { Polluted } \\
\text { creek }\end{array}$ & 873 & 2.8 & 12 & bdl & 429 & 236 & 58 & 264 & 3 & 684 & 84 & 42 & 7016 & 122 \\
\hline Angostura $^{\mathrm{b}}$ & Mine adit & 0.4 & 2.7 & 12 & bdl & 57 & 27 & 21 & 127 & 1 & 100 & 3 & 11 & 1250 & 6 \\
\hline $\mathrm{Seca}^{\mathrm{a}}$ & $\begin{array}{r}\text { Polluted } \\
\text { creek }\end{array}$ & n.a. & 5.6 & n.a & bdl & 3 & 5 & 3 & 1 & 1 & 42 & 1 & 9 & 69 & bdl \\
\hline San $_{\text {Miguel }}{ }^{\mathrm{b}}$ & Mine shaft & 1.5 & 2.3 & 9.5 & bdl & 265 & 112 & 21 & 1426 & bdl & 251 & 23 & 11 & 5890 & 13 \\
\hline Cueva Mora ${ }^{\mathrm{b}}$ & Mine adit & 3.5 & 3.3 & 9.5 & bdl & 125 & 288 & 3 & 511 & 2 & 181 & 22 & 22 & n.a. & 125 \\
\hline Aguas Teñidas & Mine shaft & 2 & 3.1 & 10 & bdl & 34 & 89 & 8 & 162 & 1 & 87 & 8 & 24 & 1370 & 51 \\
\hline Escalada $^{\mathrm{a}}$ & $\begin{array}{c}\text { Polluted } \\
\text { creek }\end{array}$ & 18 & 3.7 & 9 & bdl & 5 & 36 & 1 & 11 & 1 & 24 & 2 & 14 & 282 & 1 \\
\hline Zarza $^{\mathrm{b}}$ & Mine adit & 1 & 3.6 & 10 & bdl & 57 & 266 & 2 & 37 & 2 & 247 & 49 & 32 & 2160 & 4 \\
\hline Olivargas $^{\mathrm{a}}$ & $\begin{array}{c}\text { Polluted } \\
\text { creek }\end{array}$ & n.a. & 4.9 & 7.9 & bdl & 1 & 8 & bdl & 2 & 1 & 5 & 1 & 7 & 32 & bdl \\
\hline Gloria $^{\mathrm{b}}$ & Mine adit & 1 & 2.8 & 11 & bdl & 46 & 90 & 77 & 183 & 2 & 47 & 6 & 26 & 1310 & 3 \\
\hline $\begin{array}{l}\text { Tinto Santa } \\
\operatorname{Rosa}^{c}\end{array}$ & Mine adit & 1.4 & 3.1 & 10 & bdl & 79 & 173 & 20 & 796 & 2 & 143 & 45 & 26 & 2939 & 64 \\
\hline Villar $^{\mathrm{a}}$ & $\begin{array}{c}\text { Polluted } \\
\text { creek }\end{array}$ & n.a. & 2.8 & 12 & bdl & 32 & 122 & 4 & 15 & 2 & 77 & 23 & 32 & 1024 & 26 \\
\hline Sotiel $^{\mathrm{a}}$ & Mine adit & n.a. & 3.1 & n.a. & bdl & 20 & 65 & 3 & 38 & 3 & 78 & 26 & 14 & 819 & 47 \\
\hline Trincheron $^{\mathrm{b}}$ & Mine adit & 0.3 & 3.2 & 12 & bdl & 27 & 237 & 4 & 142 & 2 & 228 & 32 & 52 & 2050 & 5 \\
\hline Campanario $^{\mathrm{b}}$ & Mine shaft & 1 & 2.6 & 9.9 & bdl & 54 & 123 & 10 & 771 & 3 & 88 & 16 & 27 & 2780 & 52 \\
\hline Aguas Frías ${ }^{\mathrm{a}}$ & $\begin{array}{c}\text { Polluted } \\
\text { creek }\end{array}$ & 30 & 3.2 & 13 & bdl & 9 & 45 & 1 & 39 & 1 & 42 & 6 & 18 & 483 & 9 \\
\hline Torerera $^{a}$ & Mine adit & 1 & 2.8 & 11 & bdl & 62 & 263 & 15 & 88 & 1 & 218 & 68 & 50 & 2591 & 39 \\
\hline Galaparosa $^{\mathrm{a}}$ & $\begin{array}{c}\text { Polluted } \\
\text { creek }\end{array}$ & 16 & 5.2 & 8.4 & bdl & 4 & 34 & 1 & 6 & 1 & 25 & 4 & 20 & 252 & 5 \\
\hline Confesionarios $^{\mathrm{b}}$ & Spoil heap & 2 & 2 & 12 & bdl & 273 & 14 & 1 & 1115 & bdl & 110 & 1 & 9 & 5230 & bdl \\
\hline Gonzalo $^{a}$ & $\begin{array}{c}\text { Polluted } \\
\text { creek }\end{array}$ & 2 & 2.6 & 11 & bdl & 756 & 110 & 4 & 3951 & bdl & 385 & 22 & 26 & 13,783 & 4 \\
\hline $\begin{array}{l}\text { Lomero } \\
\quad \text { Poyatos }\end{array}$ & Mine adit & 5 & 2.7 & 10 & bdl & 57 & 529 & 1 & 408 & 12 & 483 & 11 & 74 & 4240 & 16 \\
\hline Pelada $^{\mathrm{a}}$ & $\begin{array}{c}\text { Polluted } \\
\text { river }\end{array}$ & 18 & 3.3 & 11 & bdl & 11 & 51 & 1 & 4 & 1 & 43 & 2 & 18 & 440 & 3 \\
\hline Perrunal $^{\mathrm{b}}$ & Mine adit & 2 & 2.9 & 8.2 & bdl & 317 & 177 & 27 & 2369 & 4 & 145 & 44 & 39 & 9130 & 46 \\
\hline Tamujoso $^{\mathrm{a}}$ & $\begin{array}{c}\text { Polluted } \\
\text { creek }\end{array}$ & 5 & 2.5 & 10 & bdl & 39 & 39 & 7 & 213 & 2 & 30 & 4 & 23 & 1336 & 7 \\
\hline El Carpio $^{\mathrm{b}}$ & Mine adit & 1.6 & 2.8 & 11 & bdl & 70 & 75 & 5 & 300 & 1 & 100 & 4 & 13 & 2030 & 15 \\
\hline San Telmo ${ }^{\mathrm{b}}$ & Spoil heap & 2 & 2.5 & 11 & bdl & 1192 & 215 & 132 & 2004 & bdl & 567 & 82 & 31 & 21,380 & 342 \\
\hline Odiel $^{\mathrm{a}}$ & $\begin{array}{l}\text { Unpolluted } \\
\text { river }\end{array}$ & 110 & 8.7 & 6.3 & 190 & bdl & 30 & bdl & bdl & 1 & 11 & bdl & 10 & 10 & bdl \\
\hline $\mathrm{Seca}^{\mathrm{d}}$ & & n.a & 7.2 & 6.8 & 91 & bdl & 17 & bdl & bdl & 1 & 11 & bdl & 16 & 30 & bdl \\
\hline
\end{tabular}


Table 3 (continued)

\begin{tabular}{|c|c|c|c|c|c|c|c|c|c|c|c|c|c|c|c|}
\hline Name & Type & $\begin{array}{l}\text { Flow rate } \\
(\mathrm{L} / \mathrm{s})\end{array}$ & $\mathrm{pH}$ & $\mathrm{Pe}$ & Alk & $\begin{array}{l}\mathrm{Al} \\
(\mathrm{mg} / \\
\mathrm{L})\end{array}$ & $\begin{array}{l}\mathrm{Ca} \\
(\mathrm{mg} / \mathrm{L})\end{array}$ & $\begin{array}{l}\mathrm{Cu} \\
(\mathrm{mg} / \mathrm{L})\end{array}$ & $\begin{array}{l}\mathrm{Fe} \\
(\mathrm{mg} / \\
\mathrm{L})\end{array}$ & $\begin{array}{l}\mathrm{K} \\
(\mathrm{mg} / \\
\mathrm{L})\end{array}$ & $\begin{array}{l}\mathrm{Mg} \\
(\mathrm{mg} / \mathrm{L})\end{array}$ & $\begin{array}{l}\mathrm{Mn} \\
(\mathrm{mg} / \mathrm{L})\end{array}$ & $\begin{array}{l}\mathrm{Na} \\
(\mathrm{mg} / \mathrm{L})\end{array}$ & $\begin{array}{l}\mathrm{SO}_{4} \\
(\mathrm{mg} / \mathrm{L})\end{array}$ & $\begin{array}{l}\mathrm{Zn} \\
(\mathrm{mg} / \mathrm{L})\end{array}$ \\
\hline
\end{tabular}

\begin{tabular}{|c|c|c|c|c|c|c|c|c|c|c|c|c|c|c|c|}
\hline & $\begin{array}{l}\text { Unpolluted } \\
\text { creek }\end{array}$ & & & & & & & & & & & & & & \\
\hline Escalada $^{\mathrm{a}}$ & $\begin{array}{l}\text { Unpolluted } \\
\text { creek }\end{array}$ & 22.6 & 8.2 & 6.2 & 155 & bdl & 28 & bdl & bdl & 1 & 12 & bdl & 15 & 10 & bdl \\
\hline Olivargas $^{\mathrm{a}}$ & $\begin{array}{l}\text { Unpolluted } \\
\text { creek }\end{array}$ & n.a. & 7.1 & 7.6 & 26 & bdl & 8 & bdl & bdl & 1 & 4 & bdl & 7 & 35 & bdl \\
\hline Villar $^{\mathrm{a}}$ & $\begin{array}{l}\text { Unpolluted } \\
\text { creek }\end{array}$ & n.a. & 6.5 & 6.1 & 64 & bdl & 25 & bdl & bdl & 1 & 16 & bdl & 15 & 109 & bdl \\
\hline Aguas Frías ${ }^{\mathrm{d}}$ & $\begin{array}{l}\text { Unpolluted } \\
\text { creek }\end{array}$ & n.a. & 7.2 & 6.8 & 91 & bdl & 17 & bdl & bdl & 1 & 11 & bdl & 16 & 30 & bdl \\
\hline Galaparosa $^{\mathrm{a}}$ & $\begin{array}{l}\text { Unpolluted } \\
\text { creek }\end{array}$ & n.a. & 7.4 & 6.5 & 51 & bdl & 15 & bdl & bdl & 1 & 11 & bdl & 13 & 63 & bdl \\
\hline Gonzalo $^{\mathrm{d}}$ & $\begin{array}{l}\text { Unpolluted } \\
\text { creek }\end{array}$ & n.a. & 7.2 & 6.8 & 91 & bdl & 17 & bdl & bdl & 1 & 11 & bdl & 16 & 30 & bdl \\
\hline Pelada $^{a}$ & $\begin{array}{l}\text { Unpolluted } \\
\text { river }\end{array}$ & n.a. & 6.4 & 6.8 & 70 & bdl & 5 & bdl & bdl & 1 & 8 & bdl & 11 & 38 & bdl \\
\hline Tamujoso $^{\mathrm{d}}$ & $\begin{array}{l}\text { Unpolluted } \\
\text { creek }\end{array}$ & n.a. & 7.2 & 6.8 & 91 & bdl & 17 & bdl & bdl & 1 & 11 & bdl & 16 & 30 & bdl \\
\hline Panera $^{\mathrm{d}}$ & $\begin{array}{l}\text { Unpolluted } \\
\text { creek }\end{array}$ & n.a. & 7.2 & 6.8 & 91 & bdl & 17 & bdl & bdl & 1 & 11 & bdl & 16 & 30 & bdl \\
\hline
\end{tabular}

n.a. not analyzed, $b d l$ below detection limit, $A l k$ alkalinity in milligram per liter as $\mathrm{CaCO}_{3}$ equivalents

${ }^{\text {a }}$ Sarmiento (2007)

${ }^{\mathrm{b}}$ Sanchez-España et al. (2005a)

${ }^{\mathrm{c}}$ Asta et al. (2010)

${ }^{\mathrm{d}}$ Sarmiento et al. (2009a)

\section{References}

Asta MP, Ayora C, Román-Ross G, Cama J, Acero P, Gault AG, Charnock JM, Bardelli F (2010) Natural attenuation of arsenic in the Tinto Santa Rosa acid stream (Iberian Pyritic Belt, SW Spain): the role of iron precipitates. Chem Geol 271(1-2):1-12. doi:10.1016 /j.chemgeo.2009.12.005

Ayora C, Caraballo MA, Macías F, Rötting TS, Carrera J, Nieto JM (2013) Acid mine drainage in the Iberian Pyrite Belt: 2. Lessons learned from recent passive remediation experiences. Environ Sci Pollut Res 20:7837-7853. doi:10.1007/s11356-013-1479-2

Ball J, Nordstrom D (1991) User's manual for WATEQ4F. U.S. Geological Survey Water-Resources Investigation Report, 91-183

Bigham JM, Schwertmann U, Traina SJ, Winland RL, Wolf M (1996) Schwertmannite and the chemical modeling of iron in acid sulfate waters. Geochim Cosmochim Acta 60(12):2111-2121. doi:10.1016 /0016-7037(96)00091-9

Cánovas CR, Olias M, Nieto JM, Sarmiento AM, Ceron JC (2007) Hydrogeochemical characteristics of the Tinto and Odiel Rivers (SW Spain). Factors controlling metal contents. Sci Total Environ 373(1):363-382. doi:10.1016/j.scitotenv.2006.11.022

Cánovas CR, Hubbard CG, Olías M, Nieto JM, Black S, Coleman ML (2008) Hydrochemical variations and contaminant load in the Rio Tinto (Spain) during flood events. J Hydrol 350(1-2):24-40. doi:10.1016/j.jhydrol.2007.11.022

Cánovas CR, Olías M, Macías F, Torres E, San Miguel EG, Galván L, Ayora C, Nieto JM (2016) Water acidification trends in a reservoir of the Iberian Pyrite Belt (SW Spain). Sci Total Environ 541:400-411. doi:10.1016/j.scitotenv.2015.09.070
Caraballo MA, Macías F, Nieto JM, Castillo J, Quispe D, Ayora C (2011b) Hydrochemical performance and mineralogical evolution of a dispersed alkaline substrate (DAS) remediating the highly polluted acid mine drainage in the full-scale passive treatment of Mina Esperanza (SW Spain). Am Mineral 96:1270-1277. doi:10.2138 lam.2011.3752

Caraballo MA, Macías F, Rötting TS, Nieto JM, Ayora C (2011a) Long term remediation of highly polluted acid mine drainage: a sustainable approach to restore the environmental quality of the Odiel river basin. Environ Pollut 159(12):3613-3619. doi:10.1016/j. envpol.2011.08.003

Caraballo MA, Rötting TS, Macías F, Nieto JM, Ayora C (2009) Field multi-step calcite and $\mathrm{MgO}$ passive system to treat acid mine drainage with high metal concentration. Appl Geochem 24:2301-2311. doi:10.1007/s11356-013-1479-2

EU Commission (2000) Directive 2000/60/EC of the European Parliament and of the Council, of 23 October 2000, establishing a framework for Community action in the field of water policy. Official Journal of the European Economics L 327/1, 22.12.2000: http://ec.europa.eu/environment/water/water-framework/index_en. html. Accessed 03 May 2016

Galván L, Olías M, Fernandez de Villarán R, Domingo Santos JM, Nieto JM, Sarmiento AM, Cánovas CR (2009) Application of the SWAT model to an AMD-affected river (Meca River, SW Spain). Estimation of transported pollutant load. J Hydrol 377:445-454. doi:10.1016/j.jhydrol.2009.09.002

Grande JA, de la Torre ML, Cerón JC, Beltrán R, Gómez T (2010) Overall hydrochemical characterization of the Iberian Pyrite Belt. Main acid mine drainage-generating sources (Huelva, SW Spain). J Hydrol 390:123-130. doi:10.1016/j.jhydrol.2010.06.001 
Johnson DB, Hallberg KB (2005) Acid mine drainage remediation options: a review. Sci Total Environ 338(1-2):3-14. doi:10.1016/j. scitotenv.2004.09.002

Macías F, Caraballo MA, Nieto JM, Rötting TS, Ayora C (2012a) Natural pretreatment and passive remediation of highly polluted acid mine drainage. J Environ Manag 104:93-100. doi:10.1016/j. jenvman.2012.03.027

Macías F, Caraballo MA, Rötting TS, Pérez-López R, Nieto JM, Ayora C (2012b) From highly polluted Zn-rich acid mine drainage to nonmetallic waters: implementation of a multi-step alkaline passive treatment system to remediate metal pollution. Sci Total Environ 433:323-330. doi:10.1016/j.scitotenv.2012.06.084

Macías F, Caraballo MA, Nieto JM (2012c) Environmental assessment and management of metal-rich wastes generated in acid mine drainage passive remediation systems. J Hazard Mater 229-230:107-114. doi:10.1016/j.jhazmat.2012.05.080

Nieto JM, Sarmiento AM, Olias M, Canovas CR, Riba I, Kalman J, Delvalls TA (2007) Acid mine drainage pollution in the Tinto and Odiel rivers (Iberian Pyrite Belt, SW Spain) and bioavailability of the transported metals to the Huelva Estuary. Environ Int 33(4):445455. doi:10.1016/j.envint.2006.11.010

Nocete F, Álex E, Nieto JM, Sáez R, Bayona MR (2005) An archaeological approach to regional environmental pollution in the southwestern Iberian Peninsula related to third millennium BC mining and metallurgy. J Archaeol Sci 32(10):1566-1576. doi:10.1016/j. jas.2005.04.012

Olias M, Nieto JM, Sarmiento AM, Cánovas CR, Galván L (2011) Water quality in the future Alcolea reservoir (Odiel River, SW Spain): a clear example of the inappropriate management of water resources in Spain. Water Resour Manag 25(1):201-215. doi:10.1007/s11269010-9695-8

Parkhurst DL, Appelo CAJ (1999) User's guide to PHREEQC (version 2) a computer program for speciation, batch reaction, one-dimensional transport, and inverse geochemical calculations. USGS WaterResources Investigations Report 99-4259. Denver, p 312
Pérez-López R, Macías F, Caraballo MA, Nieto JM, Román-Ross G, Tucoulou R, Ayora C (2011) Mineralogy and geochemistry of Znrich mine-drainage precipitates from an $\mathrm{MgO}$ passive treatment system by synchrotron-based X-ray analysis. Environ Sci Technol 45(18):7826-7833. doi:10.1021/es201667n

Sáez R, Pascual E, Toscano M, Almodóvar GR (1999) The Iberian type of volcano-sedimentary massive sulphide deposits. Mineral Deposita 34(5):549-570. doi:10.1007/s001260050220

Sanchez-España J, Lopez Pamo E, Santofimia E, Aduvire O, Reyes J, Barettino D (2005a) Acid mine drainage in the Iberian Pyrite Belt (Odiel river watershed, Huelva, SW Spain): geochemistry, mineralogy and environmental implications. Appl Geochem 20(7):1320 1356. doi:10.1016/j.apgeochem.2005.01.011

Sanchez-España J, Lopez Pamo E, Pastor E, Andrés J, Rubí J (2005b) The natural attenuation of two acidic effluents in Tharsis and La Zarza-Perrunal mines (Iberian Pyrite Belt, Huelva, Spain). Environ Geol 49(2):253-266. doi:10.1007/s00254-005-0083-2

Sarmiento AM (2007) Study of the pollution by acid mine drainage of the surface waters in the Odiel basin (SW Spain). Ph. D. Thesis, Univ. Huelva, Spain. ProQuest Dissertations Publishing, USA. http://search.proquest.com/docview/304702231. Accessed 03 May 2016

Sarmiento AM, Nieto JM, Olías M, Cánovas CR (2009a) Hydrochemical characteristics and seasonal influence on the pollution by acid mine drainage in the Odiel river Basin (SW Spain). Appl Geochem 24(4): 697-714. doi:10.1016/j.apgeochem.2008.12.025

Sarmiento AM, Olías M, Nieto JM, Cánovas CR, Delgado J (2009b) Natural attenuation processes in two water reservoirs receiving acid mine drainage. Sci Total Environ 407(6):2051-2062. doi:10.1016/j. scitotenv.2008.11.011

Younger PL, Banwart SA, Hedin RS (2002) Mine water, hydrology, pollution, remediation. Kluwer Academic Publishers, Dordrecht

Yu JY, Heo B, Choi IK, Cho JP, Chang HW (1999) Apparent solubilities of schwertmannite and ferrihydrite in natural stream waters polluted by mine drainage. Geochim Cosmochim Acta 63(19-20):34073416. doi:10.1016/S0016-7037(99)00261-6 